\title{
NPK Compound Fertilizer Foliar Application Impacts Productivity and Grain Quality of Rice
}

\begin{abstract}
A.S. Gharieb
Rice Research and Training Center, Field Crops Research Institute, Agricultural Research Center Giza, Egypt.

ABSTRACT

A field experiment was conducted during the 2018 and 2019 rice growing seasons at The Experimental Farm of Rice Research and Training Center, Sakha, Kafrelsheikh, Egypt, to study the effect of foliar application of NPK (20:20:20) or urea combined with different nitrogen levels on grain yield and quality of Sakha 109 rice variety. Urea $(46.5 \% \mathrm{~N})$ and complex paste water-soluble NPK fertilizer (20:20:20) were used as the nutrient sources for the experimental treatments. For foliar application, NPK was used at the rate of $2 \mathrm{gm}$ per liter of water and nitrogen used was at the concentration of $2 \%$ as urea. The field experiments were laid out in a Randomized Complete Block Design with four replications. The studied characteristics were chlorophyll content (SPAD value) at 55 days after transplanting, plant height at harvest, number of panicles per hill, panicle length, panicle weight, number of filled grains per panicle, unfilled grains percentage, 1000-grain weight, grain yield, straw yield and grain quality characteristics (hulling, milling and head rice percentages). $\mathrm{N}$ and $\mathrm{K}$ uptake $\left(\mathrm{kg} \mathrm{ha}^{-1}\right)$ were also determined. All studied characteristics were significantly influenced by the foliar fertilizer application in the two seasons. Application of NPK or N alone twice might improve rice grain yield and quality. The economic feasibility indicated that the application of $123.75 \mathrm{~kg} \mathrm{~N} \mathrm{ha}^{-1}$ combined with foliar application of NPK or $2 \%$ nitrogen twice recorded the highest values of gross return and net return as well as a benefit-cost ratio.
\end{abstract}

Key words: Nitrogen, Phosphorus, Potassium, Urea fertilizer, Grain yield.

\section{INTRODUCTION}

Rice is one of the staple food crops for approximately half of the global population. Therefore, rice production should significantly increase to satisfy the requirements of the world growing population. However, challenges facing in increasing rice production include, decreased arable land area, global climate change, intensified natural disasters, the high cost of fertilizers, intensified natural disasters, and frequent occurrence of diseases and pests (Wu et al., 2016)

Nitrogen is one of the most essential macronutrients for plant growth and yield. So, mineral nitrogen fertilizers are widely used in agriculture all over the world, and also in Egypt. Urea is the most common nitrogen source used in crop production particularly for rice production. This fertilizer is widely available and has a large percentage of nitrogen but relatively expensive compare to foliar fertilizers.

The foliar application increases nutrients uptake at critical growth stages and resulted in enhanced physiological activity leading to increasing yield (Kundu and Sarkar, 2009). Alam et al. (2010) indicated that, foliar application could be considered only as a supplement to soil application of nitrogen. Jagathjothi et al. (2012) reported that, foliar nutrients increased the photosynthetic rate and carbohydrate translocation and in turn increased dry matter production. They have also found that, the combined application of NPK sources with foliar spray enhanced the growth of rice. Rani et al. (2014) studied that, foliar fertilizers application effects on growth, yield, economics and nutrient uptake of rice. NPK 19:19:19 was used at the rate of
$2.5 \mathrm{~kg} \mathrm{ha}^{-1}$ at active tillering and panicle initiation stages. The results indicated that, combined application of recommended fertilizers doses with a foliar spray of NPK 19:19:19 significantly increased grain yield. Also, they found that foliar application of NPK twice at the rate of $2.5 \mathrm{~kg} \mathrm{ha}^{-1}$ produced the highest values of both gross returns and net returns. Hashem (2019) studied the NPK foliar application in combination with conventional fertilizers on rice production. This study concluded that basal application of two thirds of recommended doses of urea, superphosphate, potassium sulfate, combined with foliar spray of NPK (28:28:28) either at mid tillering + panicle initiation + flowering or at mid tillering + panicle initiation, increased rice yield, compared to a traditional method. From the economic analysis results, the combination of traditional fertilizers (urea, superphosphate and potassium sulfate) with complex water-soluble fertilizer NPK (28:28:28) could be used to uplift the net return of Sakha108 cultivation.

This study aimed to decrease the use of urea fertilizer in rice fields and to substitute it with foliar fertilizers (N: P: K 20:20:20 and 2\% nitrogen) as an approach to reduce costs and increasing production.

\section{MATERIALS AND METHODS}

This experiment was conducted during 2018 and 2019 summer rice growing seasons at the Experimental farm of Rice Research and Training Center, Sakha, Kafrelsheikh, Egypt (31 ${ }^{\circ} 5^{\prime} 17^{\prime \prime}$ North and $30^{\circ} 56^{\prime} 44^{\prime \prime}$ East at an altitude of $8 \mathrm{~m}$ from mean sea level). The main objective was to study the effect of foliar application of NPK (20:20:20) and urea combined with different nitrogen levels, on 
grain yield of Sakha 109 rice cultivars. Some chemical properties of soil of the experimental site were presented in Table 1.

Table 1: Chemical analyses of the experimental soil before planting in the 2018 and 2019 summer seasons.

\begin{tabular}{|c|c|c|}
\hline \multirow[t]{2}{*}{ Soil chemical properties } & \multicolumn{2}{|c|}{ Seasons } \\
\hline & 2018 & 2019 \\
\hline Soil texture & Clayey & Clayey \\
\hline Clay \% & 55.90 & 56.00 \\
\hline Silt \% & 31.50 & 32.00 \\
\hline Sand \% & 12.60 & 12.00 \\
\hline $\mathrm{pH}(1: 2.5$ soil suspension $)$ & 8.05 & 8.20 \\
\hline $\mathrm{Ec}\left(\mathrm{ds} . \mathrm{m}^{-1}\right)$ & 2.00 & 2.05 \\
\hline Available ammonium (ppm) & 13.50 & 12.60 \\
\hline Available Nitrate (ppm) & 10.30 & 11.80 \\
\hline Available P (ppm) & 14.00 & 12.00 \\
\hline Available K (ppm) & 350.10 & 366.50 \\
\hline \multicolumn{3}{|l|}{ Anions (meq.L $\mathrm{L}^{-1}$ ) } \\
\hline $\mathrm{CO}_{3}^{--}$ & 0.00 & 0.00 \\
\hline $\mathrm{HCO}_{3}^{-}$ & 5.60 & 5.00 \\
\hline $\mathrm{Cl}^{-}$ & 14.00 & 14.00 \\
\hline $\mathrm{SO}_{4}^{--}$ & 2.70 & 2.00 \\
\hline \multicolumn{3}{|l|}{ Cations( meq. $\mathrm{L}^{-1}$ ) } \\
\hline $\mathrm{Ca}^{++}$ & 7.20 & 6.00 \\
\hline $\mathrm{Mg}^{++}$ & 2.60 & 1.50 \\
\hline $\mathrm{Na}^{++}$ & 12.00 & 13.00 \\
\hline $\mathrm{K}^{+}$ & 0.50 & 0.50 \\
\hline
\end{tabular}

Treatments contain both foliar and soil application of different fertilizers. Treatments consisted of soil application of urea combined with foliar spray of NPK (20:20:20) or 2\% nitrogen concentration at different growth stages. The recommended dose of nitrogen fertilizer was 165.6 $\mathrm{kg} \mathrm{N} \mathrm{ha}{ }^{-1}$ (urea, $46.5 \% \mathrm{~N}$ ). Nitrogen fertilizer was added into splits first one was (two-third) of recommended rate as basal application and second one (one-third) was applied at 30 days after transplanting (DAT) Complex paste water-soluble fertilizer NPK (20:20:20) were used as the nutrient sources. NPK was used at the rate of $2 \mathrm{~g} / \mathrm{L}$. Solutions of $2 \%$ nitrogen, $\mathrm{N}$ was prepared from urea $(46.5 \% \mathrm{~N})$. The treatments schedule was as illustrated in Table 2.

Field experiments were laid out in a Randomized Complete Block Design with four replications. Plot size was $12 \mathrm{~m}^{2}(3 \mathrm{X} 4 \mathrm{~m})$. The experimental area was plowed twice and well leveled. The nursery bed was sown on the $11^{\text {th }}$ and $14^{\text {th }}$ of May in both seasons, respectively. 27-day old seedlings were used at $20 \times 20 \mathrm{~cm}$ transplanting spacing. The crop was harvested at full maturity. The border and sampling rows were harvested separately. $10 \mathrm{~m}^{2}$ of each plot was harvested and the weight of grain and straw were recorded. Plant samples (five hills each) were taken randomly from each plot at 55 DAT to determine chlorophyll content (SPAD value). At harvest, plant height $(\mathrm{cm})$ and the number of panicles per hill were measured. Ten panicles were collected randomly to estimate the panicle length $(\mathrm{cm})$, panicle weight $(\mathrm{g})$, number of filled grains per panicle, unfilled grains percentage, 1000-grain weight (g), grain and straw yield $\left(\mathrm{t} \mathrm{ha}^{-1}\right)$ and grain quality characteristics (hulling, milling and head rice percentages). The nitrogen content of milled grains was measured using the Microkieldahl method (Jackson 1967) to determine nitrogen uptake. The Potassium content of grain was determined to calculate potassium uptake using Elico CL378 Flame Photometer (RHYS international LTD, India) according to Peterpurgski (1968) scheme.

Table 2: Schedule of fertilization treatments

\begin{tabular}{llll}
\hline Treatment & Designation & Soil application $($ SA) & Foliar application (FA) \\
\hline T1 & Control & Zero nitrogen & Distilled water spray \\
\hline T2 & $50 \%$ SA+1 NPK FA & $50 \%$ of recommended N dose & NPK 2 g/L once at 20 DAT \\
\hline T3 & $50 \%$ SA+1 N FA & $50 \%$ of recommended N dose & $2 \%$ once at 20 DAT. \\
\hline T4 & $50 \%$ SA+2 NPK FA & $50 \%$ of recommended N dose & NPK 2 g/L twice at 20 \&40 DAT \\
\hline T5 & $50 \%$ SA+2 N FA & $50 \%$ of recommended N dose & $2 \%$ twice at 20 \&40 DAT \\
\hline T6 & $75 \%$ SA+1 NPK FA & $75 \%$ of recommended N dose & NPK 2 g/L once at 20 DAT \\
\hline T8 & $75 \%$ SA+1 N FA & $75 \%$ of recommended N dose & $2 \%$ once at 20 DAT. \\
\hline T9 & $75 \%$ SA+2 NPK FA & $75 \%$ of recommended N dose & NPK 2 g/L twice at 20 \&40 DAT \\
\hline T10 & 100\% SA & $75 \%$ of recommended N dose & N 2\% twice at 20 \&40 DAT \\
\hline
\end{tabular}

*SA: N soil application

$* 1 \mathrm{~F}$ and $2 \mathrm{~F}$ : Foliar spray once or twice, respectively

*100\%: N recommended dose

*DAT: Days after transplanting 


\section{Economic feasibility}

An economic analysis was conducted using to measure the net return and the benefit-cost ratio for each treatment (Program et al., 1988).

Cost of cultivation (L.E. ha ${ }^{-1}$ ):

The cost of farming for each treatment is calculated in Egyptian Pounds (L.E.). Data of inputs cost were calculated as a cost of land preparation, seeding, transportation, irrigation, fertilizers, weeding, harvesting and other expenses.

Gross return (L.E. ha' ${ }^{-1}$ :

Gross return was estimated based on the harvested straw and grain yields $\left(\mathrm{t} \mathrm{ha}^{-1}\right)$ in Egyptian pounds. One ton of straw value was 250 L.E., one ton of rice grain value was 4000 L.E. in both seasons.

Net return (L.E. ha' $\left.{ }^{-1}\right)$ :

Net return was estimated as the difference between total revenue from the sale of harvested rice grains and total costs (fixed and variable cost of rice yield).

\section{Benefit-cost ratio:}

Calculated by the formula, $\mathrm{B}: \mathrm{C}$ ratio $=$ Gross return/Cost of cultivation

The collected data were subjected to statistical analysis according to the procedure described by Gomez and Gomez (1984).Treatment means were compared by Duncan's Multiple Range Test (Duncan, 1955). All statistical analyses were done using Costat Statistical Software - CoHort Software.

\section{RESULTS AND DISCUSSION}

The results of chlorophyll content in leaves at 55 days after transplanting (DAT) and plant height in the 2018 and 2019 seasons are presented in Table 3. Application of soil or foliar nutrients resulted in a significant increase in chlorophyll content and plant height compared with control treatment in both seasons. Adding $123.75 \mathrm{~kg} \mathrm{~N} \mathrm{ha}^{-1}$ (75\%SA) as soil application along with foliar spraying of NPK (20:20:20) twice at 20 and 40 DAT (T8) recorded the highest values of chlorophyll content and plant height in both seasons. There were no significant differences in chlorophyll content and plant height among the recommended dose of urea $100 \%$ SA $\left(165 \mathrm{~kg} \mathrm{~N} \mathrm{ha}^{-1}\right)$ as a soil application and (T8 and T9) $123.75 \mathrm{~kg} \mathrm{~N} \mathrm{ha}^{-1}$ combined with foliar application of NPK or $2 \% \mathrm{~N}$ added once or twice. That increase might be due to balanced nutrient supply at different growth stages viz., mid tillering, panicle initiation and flowering stages. The foliar application of NPK or $\mathrm{N}$ at different growth stages might have increased the plant height due to the fact that the nutrients supply to rice plants at different growth stages might help cell elongation and increase photosynthetic rate. These findings are supported by the work done by Manik et al., (2016) and Hashem (2019).

Number of panicles $\mathrm{m}^{2}$ (Table 3), panicle length, panicle weight, number of filled grains per panicle (Table 4) and 1000-grain weight (Table 5) were significant increased by the application of any studied $\mathrm{N}$ source relative to the control treatment (without $\mathrm{N}$ ) in both seasons. The opposite was true in number of unfilled grains per panicle. The plants treated by $\mathrm{T} 8\left(123.75 \mathrm{~kg} \mathrm{Nha}^{-1}+\right.$ foliar spray with NPK at 20 and 40 DAT) recorded the maximum values of the mentioned traits in the two seasons. The maximum values of the after-mentioned traits were obtained from applied T8 $\left(123.75 \mathrm{~kg} \mathrm{~N} \mathrm{ha}^{-1}+\right.$ twice NPK foliar spray), which was parallel with T9 (123.75 kg N ha ${ }^{-1}$ combined with spray of $2 \% \mathrm{~N}$ concentration at 20 and 40 DAT) and the recommended $\mathrm{N}$ rate $\left(165 \mathrm{~kg} \mathrm{~N} \mathrm{ha}^{-1}\right)$ in both seasons.

Table 3: Chlorophyll content, plant height and number of panicles $\mathrm{m}^{-2}$ as affected by different treatments in the 2018 and 2019 seasons.

\begin{tabular}{lcccccc}
\hline \multirow{2}{*}{ Treatment } & \multicolumn{2}{c}{ Chlorophyll (SPAD) } & \multicolumn{2}{c}{ Plant height (cm) } & \multicolumn{2}{c}{ No. of panicles $\mathbf{~ m}^{-2}$} \\
\cline { 2 - 7 } & $\mathbf{2 0 1 8}$ & $\mathbf{2 0 1 9}$ & $\mathbf{2 0 1 8}$ & $\mathbf{2 0 1 9}$ & $\mathbf{2 0 1 8}$ & $\mathbf{2 0 1 9}$ \\
\hline (T1) Control & $36.23 \mathrm{e}$ & $36.03 \mathrm{f}$ & $73.70 \mathrm{f}$ & $78.00 \mathrm{~d}$ & $316.70 \mathrm{f}$ & $308.33 \mathrm{f}$ \\
\hline (T2) 50\%SA+1 NPK FA & $40.67 \mathrm{~d}$ & $41.44 \mathrm{de}$ & $79.00 \mathrm{e}$ & $84.30 \mathrm{c}$ & $445.80 \mathrm{e}$ & $443.33 \mathrm{e}$ \\
\hline (T3) 50\%SA+1 N FA & $40.51 \mathrm{~d}$ & $41.17 \mathrm{e}$ & $79.30 \mathrm{de}$ & $85.70 \mathrm{bc}$ & $433.30 \mathrm{e}$ & $441.67 \mathrm{e}$ \\
\hline (T4) 50\%SA+2 NPK FA & $41.99 \mathrm{c}$ & $42.66 \mathrm{c}$ & $84.70 \mathrm{c}$ & $88.00 \mathrm{abc}$ & $489.60 \mathrm{~cd}$ & $482.00 \mathrm{~cd}$ \\
\hline (T5) 50\%SA+2 N FA & $41.68 \mathrm{c}$ & $42.21 \mathrm{~cd}$ & $82.70 \mathrm{~cd}$ & $86.00 \mathrm{bc}$ & $472.90 \mathrm{~d}$ & $467.83 \mathrm{de}$ \\
\hline (T6) 75\%SA+1 NPK FA & $43.16 \mathrm{ab}$ & $44.50 \mathrm{ab}$ & $89.70 \mathrm{ab}$ & $89.30 \mathrm{ab}$ & $516.70 \mathrm{bc}$ & $535.33 \mathrm{ab}$ \\
\hline (T7) 75\%SA+1 N FA & $42.67 \mathrm{bc}$ & $43.71 \mathrm{~b}$ & $85.70 \mathrm{bc}$ & $88.30 \mathrm{abc}$ & $510.40 \mathrm{bc}$ & $514.54 \mathrm{bc}$ \\
\hline (T8) 75\%SA+2 NPK FA & $44.22 \mathrm{a}$ & $45.32 \mathrm{a}$ & $93.00 \mathrm{a}$ & $91.70 \mathrm{a}$ & $576.70 \mathrm{a}$ & $568.33 \mathrm{a}$ \\
\hline (T9) 75\%SA+2 N FA & $43.78 \mathrm{a}$ & $45.13 \mathrm{a}$ & $89.70 \mathrm{ab}$ & $89.30 \mathrm{ab}$ & $564.30 \mathrm{a}$ & $554.67 \mathrm{a}$ \\
\hline (T10) 100\% SA & $43.63 \mathrm{ab}$ & $44.56 \mathrm{ab}$ & $90.70 \mathrm{a}$ & $90.00 \mathrm{ab}$ & $542.30 \mathrm{ab}$ & $539.67 \mathrm{ab}$ \\
\hline F-test & $* *$ & $*$ & $*$ & $* *$ & $* *$ & $* *$
\end{tabular}

*,** and N.S. indicate $\mathrm{P}<0.05, \mathrm{P}<0.01$ and not significant, respectively. Means of each factor designated by the same latter are not significantly different at 5\% level using Duncan's Multiple Range Test 
Table 4: Panicle length, panicle weight, No. of filled grains panicle ${ }^{-1}$ and unfilled grains as affected by different treatments in the 2018 and 2019 seasons.

\begin{tabular}{lcccccccc}
\hline Treatment & \multicolumn{2}{c}{$\begin{array}{c}\text { Panicle length } \\
\text { (cm) }\end{array}$} & \multicolumn{2}{c}{$\begin{array}{c}\text { Panicle weight } \\
\text { (g) }\end{array}$} & \multicolumn{2}{c}{ No. of filled grains } & \multicolumn{2}{c}{$\begin{array}{c}\text { Unfilled grains } \\
\text { (\%) }\end{array}$} \\
\cline { 2 - 10 } & $\mathbf{2 0 1 8}$ & $\mathbf{2 0 1 9}$ & $\mathbf{2 0 1 8}$ & $\mathbf{2 0 1 9}$ & $\mathbf{2 0 1 8}$ & $\mathbf{2 0 1 9}$ & $\mathbf{2 0 1 8}$ & $\mathbf{2 0 1 9}$ \\
\hline (T1) Control & $17.8 \mathrm{~d}$ & $18.2 \mathrm{c}$ & $2.7 \mathrm{e}$ & $2.7 \mathrm{~d}$ & $89.7 \mathrm{e}$ & $94.5 \mathrm{e}$ & $11.0 \mathrm{a}$ & $8.7 \mathrm{a}$ \\
\hline (T2) 50\%SA+1 NPK FA & $19.4 \mathrm{c}$ & $19.8 \mathrm{~b}$ & $2.8 \mathrm{~d}$ & $2.9 \mathrm{c}$ & $100.2 \mathrm{~d}$ & $103.2 \mathrm{~d}$ & $7.8 \mathrm{bc}$ & $6.4 \mathrm{bc}$ \\
\hline (T3) 50\%SA+1 N FA & $18.7 \mathrm{c}$ & $19.3 \mathrm{~b}$ & $2.8 \mathrm{~d}$ & $2.9 \mathrm{c}$ & $99.3 \mathrm{~d}$ & $103.1 \mathrm{~d}$ & $8.4 \mathrm{~b}$ & $6.6 \mathrm{~b}$ \\
\hline (T4) 50\%SA+2 NPK FA & $19.2 \mathrm{c}$ & $19.7 \mathrm{~b}$ & $2.9 \mathrm{~cd}$ & $3.0 \mathrm{~b}$ & $105.2 \mathrm{bcd}$ & $107.5 \mathrm{c}$ & $6.8 \mathrm{bc}$ & $5.7 \mathrm{bcd}$ \\
\hline (T5) 50\%SA+2 N FA & $19.5 \mathrm{c}$ & $19.9 \mathrm{~b}$ & $2.9 \mathrm{~cd}$ & $3.0 \mathrm{~b}$ & $104.4 \mathrm{~cd}$ & $107.6 \mathrm{c}$ & $7.2 \mathrm{bc}$ & $5.7 \mathrm{bcd}$ \\
\hline (T6) 75\%SA+1 NPK FA & $22.7 \mathrm{ab}$ & $23.4 \mathrm{a}$ & $3.0 \mathrm{abc}$ & $3.1 \mathrm{a}$ & $112.7 \mathrm{abc}$ & $116.3 \mathrm{ab}$ & $7.3 \mathrm{bc}$ & $5.5 \mathrm{bcd}$ \\
\hline (T7) 75\%SA+1 N FA & $22.3 \mathrm{~b}$ & $22.9 \mathrm{a}$ & $3.0 \mathrm{abc}$ & $3.1 \mathrm{a}$ & $111.4 \mathrm{abc}$ & $115.6 \mathrm{~b}$ & $7.4 \mathrm{bc}$ & $5.4 \mathrm{bcd}$ \\
\hline (T8) 75\%SA+2 NPK FA & $23.5 \mathrm{a}$ & $23.7 \mathrm{a}$ & $3.2 \mathrm{a}$ & $3.2 \mathrm{a}$ & $116.5 \mathrm{a}$ & $120.0 \mathrm{a}$ & $6.1 \mathrm{c}$ & $4.4 \mathrm{~d}$ \\
\hline (T9) 75\%SA+2 N FA & $23.2 \mathrm{ab}$ & $23.7 \mathrm{a}$ & $3.1 \mathrm{ab}$ & $3.2 \mathrm{a}$ & $115.3 \mathrm{a}$ & $118.7 \mathrm{ab}$ & $6.4 \mathrm{bc}$ & $4.7 \mathrm{~cd}$ \\
\hline (T10) 100\% SA & $23.0 \mathrm{ab}$ & $23.3 \mathrm{a}$ & $3.0 \mathrm{abc}$ & $3.1 \mathrm{a}$ & $113.8 \mathrm{ab}$ & $117.2 \mathrm{ab}$ & $6.7 \mathrm{bc}$ & $5.1 \mathrm{bcd}$ \\
\hline F-test & $* *$ & $* *$ & $* *$ & $* *$ & $*$ & $* *$ & $*$ & $*$ \\
\hline
\end{tabular}

$*$, ** and N.S. indicate $\mathrm{P}<0.05, \mathrm{P}<0.01$ and not significant, respectively. Means of each factor designated by the same latter are not significantly different at $5 \%$ level using Duncan's Multiple Range Test

These results might discriminate the fact that, foliar application of NPK at different growth stages might increase the availability of those nutrients which might increase the absorption and the translocation of nutrients to the rice grain. Therefore, photosynthesis improved, producing a great number of filled grains along with improvement in sink size. Moreover, increased total sink size because of increases in both panicles number and spikelet number panicle ${ }^{-1}$. Meantime, it might be the foliar application of NPK significantly increased leaf Ncontent for both flag leaf and leaves besides the flag leaf. Thereby, Rubisco (Ribulose-L5- Bisphosphate Carboxylase) activity in the flag leaves was higher for the plants that received NPK. This might have increased the grain filling as well as grain weight. Similar results were obtained by Rani et al., (2014), Das et al., (2018) Hashem (2019) and Shrestha et al., (2020)

The NPK nutrients applied as a foliar spray at different growth stages might have resulted in the rapid availability and uptake of those nutrients leading to faster crop response compared to soil application which increased significantly the number of panicles per unit area. Similar results have been reported by Jagathjothi et al., (2012), Rani et al., (2014) and Hashem (2019).

Data in Table 5 show that rice grain yield $\mathrm{ha}^{-1}$ was significantly increased by the application of either the recommended $\mathrm{N}$ rate alone $100 \%$ SA (165 $\left.\mathrm{kg} \mathrm{N} \mathrm{ha}^{-1}\right)$ or the other nitrogen rates (123.75 kg N $\mathrm{ha}^{-1}$ (75\%SA) and $82.5 \mathrm{~kg} \mathrm{~N} \mathrm{ha}^{-1}$ (50\%SA) with foliar spray of NPK and N once and twice) compared with the control treatment in the two seasons. Plants treated with T8 $\left(123.75 \mathrm{~kg} \mathrm{~N} \mathrm{ha}^{-1}\right.$ combined with foliar application of NPK at 20 and 40 DAT) pronouncedly produced the highest grain yield followed by $\mathrm{T} 9$ those treated with $(123.75 \mathrm{~kg}$
$\mathrm{N} \mathrm{ha}{ }^{-1}$ combined with foliar application of $2 \% \mathrm{~N}$ concentration twice) with no significant differences between the two treatments in the two seasons. Application of $\left(123.75 \mathrm{~kg} \mathrm{~N} \mathrm{ha}{ }^{-1}\right)$ as a soil application among with foliar spraying with NPK (20:20:20) or $2 \% \mathrm{~N}$ twice out yielded the application of the recommended $\mathrm{N}$ rate alone as a soil application in the two seasons. Any increase in one or more of the yield components without a decrease in the others will lead to an increase in grain yield. Therefore, increases in grain yield due to fertilizer foliar application was a logical resultant due to the increases in yield components, i.e. number of panicles per $\mathrm{m} 2$, filled grains percentage and the number of grain per panicle (Manik et al., 2016 and Shrestha et al., 2020). Moreover, the increase in grain yield associated with the utilization of NPK foliar application might be attributed to balancing NPK supply that enhanced intensive chlorophyll synthesis and sufficient translocation of assimilates to production parts. These findings are supported by the work done by Alam et al., (2010), Manik et al., (2016), Hervé et al., (2017), Mohan et al., (2017) ans Hashem (2019).

The increases percentages in grain yield due to the nitrogen fertilizer combination were significant in both seasons. The highest percentage of increase in grain yield was obtained with soil application of T8 and T9 (123.75 kg N ha-1 with NPK (20:20:20) foliar spray twice or $2 \% \mathrm{~N}$ ). The increasing percentage was decreased by decreasing nitrogen rate to $50 \%$ SA with foliar spraying once by $2 \% \mathrm{~N}$ in the two seasons.

The $\mathrm{N}$ fertilizer treatments had a significant effect on rice straw yield in both seasons (Table 5). 
Table 5: 1000-grain weight, grain yield and straw yield as affected by different treatments in 2018 and 2019 seasons.

\begin{tabular}{|c|c|c|c|c|c|c|c|c|}
\hline \multirow[t]{2}{*}{ Treatment } & \multicolumn{2}{|c|}{$\begin{array}{c}\text { 1000-grain } \\
\text { weight }(\mathrm{g})\end{array}$} & \multicolumn{2}{|c|}{$\begin{array}{c}\text { Grain yield } \\
\qquad\left(\mathrm{t} \mathrm{ha}^{-1}\right)\end{array}$} & \multicolumn{2}{|c|}{$\begin{array}{c}\text { Straw yield } \\
\left(\mathrm{t} \mathrm{ha}^{-1}\right)\end{array}$} & \multicolumn{2}{|c|}{$\begin{array}{l}\text { The increase in } \\
\text { grain yield }(\%)\end{array}$} \\
\hline & 2018 & 2019 & 2018 & 2019 & 2018 & 2019 & 2018 & 2019 \\
\hline (T1) Control & $24.93 \mathrm{~g}$ & $26.28 \mathrm{~d}$ & $6.21 \mathrm{e}$ & $6.46 \mathrm{e}$ & $6.46 \mathrm{e}$ & $8.88 \mathrm{c}$ & - & - \\
\hline (T2) $50 \% \mathrm{SA}+1 \mathrm{NPK} F A$ & $26.04 \mathrm{f}$ & $26.82 \mathrm{~d}$ & $7.50 \mathrm{~d}$ & $7.30 \mathrm{~d}$ & $7.30 \mathrm{~d}$ & $10.37 \mathrm{~b}$ & $20.77 \mathrm{de}$ & $13.00 \mathrm{~d}$ \\
\hline (T3) $50 \% \mathrm{SA}+1 \mathrm{~N} \mathrm{FA}$ & $25.81 \mathrm{f}$ & $26.8 \mathrm{~d}$ & $7.23 \mathrm{~d}$ & $7.29 \mathrm{~d}$ & $7.29 \mathrm{~d}$ & $10.03 \mathrm{~b}$ & $16.43 \mathrm{e}$ & $12.85 \mathrm{~d}$ \\
\hline (T4) $50 \% \mathrm{SA}+2 \mathrm{NPK} F A$ & $27.35 \mathrm{de}$ & $27.95 \mathrm{c}$ & $8.14 \mathrm{c}$ & $8.34 \mathrm{c}$ & $8.34 \mathrm{c}$ & $10.81 \mathrm{~b}$ & $31.08 \mathrm{c}$ & $29.10 \mathrm{c}$ \\
\hline (T5) $50 \% \mathrm{SA}+2 \mathrm{NFA}$ & $27.14 \mathrm{e}$ & $27.98 \mathrm{c}$ & $8.01 \mathrm{c}$ & $8.23 \mathrm{c}$ & $8.23 \mathrm{c}$ & $10.67 \mathrm{~b}$ & $28.99 \mathrm{~cd}$ & $27.40 \mathrm{c}$ \\
\hline (T6) $75 \% \mathrm{SA}+1 \mathrm{NPK} F A$ & $28.29 b c$ & $29.2 \mathrm{ab}$ & $9.31 \mathrm{~b}$ & $9.65 \mathrm{~b}$ & $9.65 \mathrm{~b}$ & $11.87 \mathrm{a}$ & $49.92 \mathrm{ab}$ & $49.38 \mathrm{~b}$ \\
\hline (T7) $75 \% \mathrm{SA}+1 \mathrm{~N} \mathrm{FA}$ & $27.97 \mathrm{~cd}$ & $29.01 \mathrm{~b}$ & $9.17 \mathrm{~b}$ & $9.54 \mathrm{~b}$ & $9.54 \mathrm{~b}$ & $11.80 \mathrm{a}$ & $47.67 \mathrm{~b}$ & $47.68 \mathrm{~b}$ \\
\hline (T8) $75 \% \mathrm{SA}+2 \mathrm{NPK} F A$ & $29.28 \mathrm{a}$ & $30.17 \mathrm{a}$ & $10.23 \mathrm{a}$ & $10.44 \mathrm{a}$ & $10.44 \mathrm{a}$ & $12.58 \mathrm{a}$ & $64.73 \mathrm{a}$ & $61.61 \mathrm{a}$ \\
\hline (T9) $75 \% \mathrm{SA}+2 \mathrm{~N} \mathrm{FA}$ & $28.99 \mathrm{ab}$ & $29.83 \mathrm{ab}$ & $10.12 \mathrm{a}$ & $10.07 \mathrm{a}$ & $10.07 \mathrm{ab}$ & $12.77 \mathrm{a}$ & $62.96 \mathrm{a}$ & $55.88 \mathrm{ab}$ \\
\hline (T10) $100 \%$ SA & $28.6 \mathrm{abc}$ & $29.47 \mathrm{ab}$ & $9.14 \mathrm{~b}$ & $9.76 \mathrm{~b}$ & $9.76 \mathrm{ab}$ & $12.12 \mathrm{a}$ & $47.18 \mathrm{~b}$ & $51.08 \mathrm{~b}$ \\
\hline
\end{tabular}

*, ** and N.S. indicate $\mathrm{P}<0.05, \mathrm{P}<0.01$ and not significant, respectively. Means of each factor designated by the same latter are not significantly different at $5 \%$ level using Duncan's Multiple Range Test

The control treatment produced the least straw yield in both seasons. The application of $(123.75 \mathrm{~kg}$ $\mathrm{N} \mathrm{ha}{ }^{-1}$ as a soil application combined with foliar application of $2 \% \mathrm{~N}$ twice or $165 \mathrm{~kg} \mathrm{~N} \mathrm{ha}^{-1}$ ), produced similarly the highest straw yield in the two seasons. This might be due to an increases in plant height and number of tillers per unite area. Foliar NPK application might have resulted in a rapid availability and uptake of nutrients leading to faster crop response which increased the dry matter production as well as straw yields. Metwally et al., (2020) indicated that, foliar application helps in the effective absorption of nutrients at critical growth stages and resulted in enhanced physiological activity leading to better growth. These results are in good harmony with that recorded by Manik et al., (2016) and Mohan et al., (2017).

The grain quality characteristics (hulling milling and head rice percentages) were considered as the most important traits that affect rice quality and consumer demand. Table (6) showed hulling, milling and head rice percentages as affected by different treatments in 2018 and 2019 seasons. Data indicated clearly that plants that received either foliar or soil fertilizers exhibited a significant increases compared to the control (without $\mathrm{N}$ application). Increasing nitrogen rate from $(50 \% \mathrm{SA}$ to $100 \% \mathrm{SA}$ ) $82.5 \mathrm{~kg} \mathrm{~N}^{-1}$ to $165 \mathrm{~kg} \mathrm{~N}^{-1}$ as a soil application along with foliar spraying of NPK or $\mathrm{N}$ were markedly increased hulling, milling and head rice percentages in both seasons. The best significant grain quality were obtained from (123.75 $\mathrm{kg} \mathrm{N} \mathrm{ha}^{-1}$ combined with NPK foliar application and $2 \% \mathrm{~N}$ once or twice) and recommended dose (165 $\mathrm{kg} \mathrm{N} \mathrm{ha}{ }^{-1}$ ) in the two seasons. Okasha et al., (2019) reported that, foliar spray of fertilizer at different growth stages would be recommended for improving rice quality and productivity of Giza 179.

Table 6: hulling, milling and head rice percentages as affected by different treatments in the 2018 and 2019 seasons.

\begin{tabular}{lcccccc}
\hline \multirow{2}{*}{ Treatment } & \multicolumn{2}{c}{ Hulling (\%) } & \multicolumn{2}{c}{ Milling (\%) } & \multicolumn{2}{c}{ Head rice (\%) } \\
\cline { 2 - 7 } & $\mathbf{2 0 1 8}$ & $\mathbf{2 0 1 9}$ & $\mathbf{2 0 1 8}$ & $\mathbf{2 0 1 9}$ & $\mathbf{2 0 1 8}$ & $\mathbf{2 0 1 9}$ \\
\hline (T1) Control & $79.67 \mathrm{c}$ & $76.66 \mathrm{~b}$ & $69.70 \mathrm{~b}$ & $66.67 \mathrm{~d}$ & $60.07 \mathrm{e}$ & $64.44 \mathrm{~d}$ \\
\hline (T2) 50\%SA+1 NPK FA & $84.11 \mathrm{~b}$ & $81.14 \mathrm{a}$ & $74.15 \mathrm{a}$ & $72.78 \mathrm{bc}$ & $65.00 \mathrm{~cd}$ & $68.87 \mathrm{bc}$ \\
\hline (T3) 50\%SA+1 N FA & $84.11 \mathrm{~b}$ & $82.26 \mathrm{a}$ & $74.18 \mathrm{a}$ & $73.67 \mathrm{ab}$ & $63.56 \mathrm{~d}$ & $69.03 \mathrm{bc}$ \\
\hline (T4) 50\%SA+2 NPK FA & $85.11 \mathrm{a}$ & $82.33 \mathrm{a}$ & $74.23 \mathrm{a}$ & $72.55 \mathrm{bc}$ & $65.00 \mathrm{~cd}$ & $70.03 \mathrm{ab}$ \\
\hline (T5) 50\%SA+2 N FA & $85.37 \mathrm{a}$ & $82.30 \mathrm{a}$ & $74.91 \mathrm{a}$ & $71.44 \mathrm{c}$ & $66.37 \mathrm{bc}$ & $68.08 \mathrm{c}$ \\
\hline (T6) 75\%SA+1 NPK FA & $86.26 \mathrm{a}$ & $81.27 \mathrm{a}$ & $75.41 \mathrm{a}$ & $73.89 \mathrm{ab}$ & $69.30 \mathrm{a}$ & $70.57 \mathrm{ab}$ \\
\hline (T7) 75\%SA+1 N FA & $85.33 \mathrm{a}$ & $82.30 \mathrm{a}$ & $74.98 \mathrm{a}$ & $73.89 \mathrm{ab}$ & $64.88 \mathrm{~cd}$ & $70.41 \mathrm{ab}$ \\
\hline (T8) 75\%SA+2 NPK FA & $85.18 \mathrm{a}$ & $82.28 \mathrm{a}$ & $75.23 \mathrm{a}$ & $73.89 \mathrm{ab}$ & $69.50 \mathrm{a}$ & $70.44 \mathrm{ab}$ \\
\hline (T9) 75\%SA+2 N FA & $85.40 \mathrm{a}$ & $82.33 \mathrm{a}$ & $75.17 \mathrm{a}$ & $74.77 \mathrm{a}$ & $68.89 \mathrm{a}$ & $71.73 \mathrm{a}$ \\
\hline (T10) 100\% SA & $85.67 \mathrm{a}$ & $81.13 \mathrm{a}$ & $74.88 \mathrm{a}$ & $73.59 \mathrm{ab}$ & $67.89 \mathrm{ab}$ & $70.04 \mathrm{ab}$ \\
\hline F-test & $*$ & $* *$ & $*$ & $* *$ & $* *$ \\
\hline *, ** and N.S. indicate P<0.05, P<0.01 and not significant, respectively. Means of each factor designated by the same latter are not \\
significantly different at 5\% level using Duncan's Multiple Range Test
\end{tabular}


Pan et al., (2013) found that, foliar fertilizer application improved the rice grain quality characteristics.

Nitrogen and potassium uptakes $\left(\mathrm{kg} \mathrm{ha}^{-1}\right)$ by rice yield grains at harvest were presented in Figs. 1 and 2. NPK nutrients had significant effects on $\mathrm{N}$ and $\mathrm{K}$ uptake. Application of (123.75 $\mathrm{kg} \mathrm{N} \mathrm{ha}^{-1}+$ NPK as a foliar spray twice T8) significantly recorded higher $\mathrm{N}$ and $\mathrm{K}$ uptake in grains, followed by any of $\left(123.75 \mathrm{~kg} \mathrm{~N}^{-1}+2 \% \mathrm{~N}\right.$ as a spray twice T9), recommended dose (165 kg N ha-1 $\mathrm{T} 10)$ and (123.75 $\mathrm{kg} \mathrm{N} \mathrm{ha}^{-1}+\mathrm{NPK}$ or $2 \% \mathrm{~N}$ as a foliar spray once T6 or T7) in both seasons. Foliar application of NPK at different growth stages increased both grain yield and the absorption of those nutrients and might have resulted in the increased uptake of $\mathrm{N}, \mathrm{P}$ and $\mathrm{K}$ by rice grains.

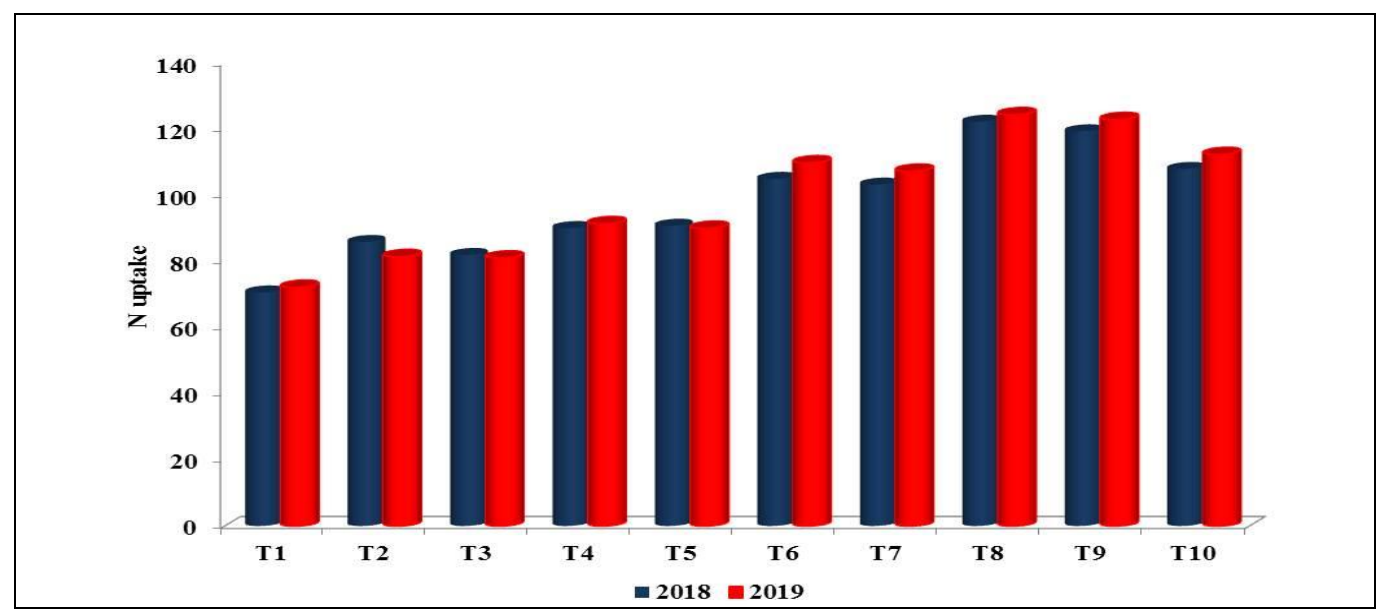

Fig 1: Nitrogen uptake $\left(\mathrm{kg} \mathrm{ha}^{-1}\right)$ as affected by different treatments in 2018 and 2019 seasons.

Where is:

\section{T1: Control}

T2: $50 \%$ SA+1 NPK FA

T3: $50 \% \mathrm{SA}+1 \mathrm{~N}$ FA

T4: $50 \%$ SA+2 NPK FA

T5: $50 \% \mathrm{SA}+2 \mathrm{~N}$ FA
T6: $75 \% \mathrm{SA}+1$ NPK FA

T7: 75\%SA+1 N FA

T8: $75 \% \mathrm{SA}+2$ NPK FA

T9: 75\%SA+2 N FA

T10: $100 \%$ SA

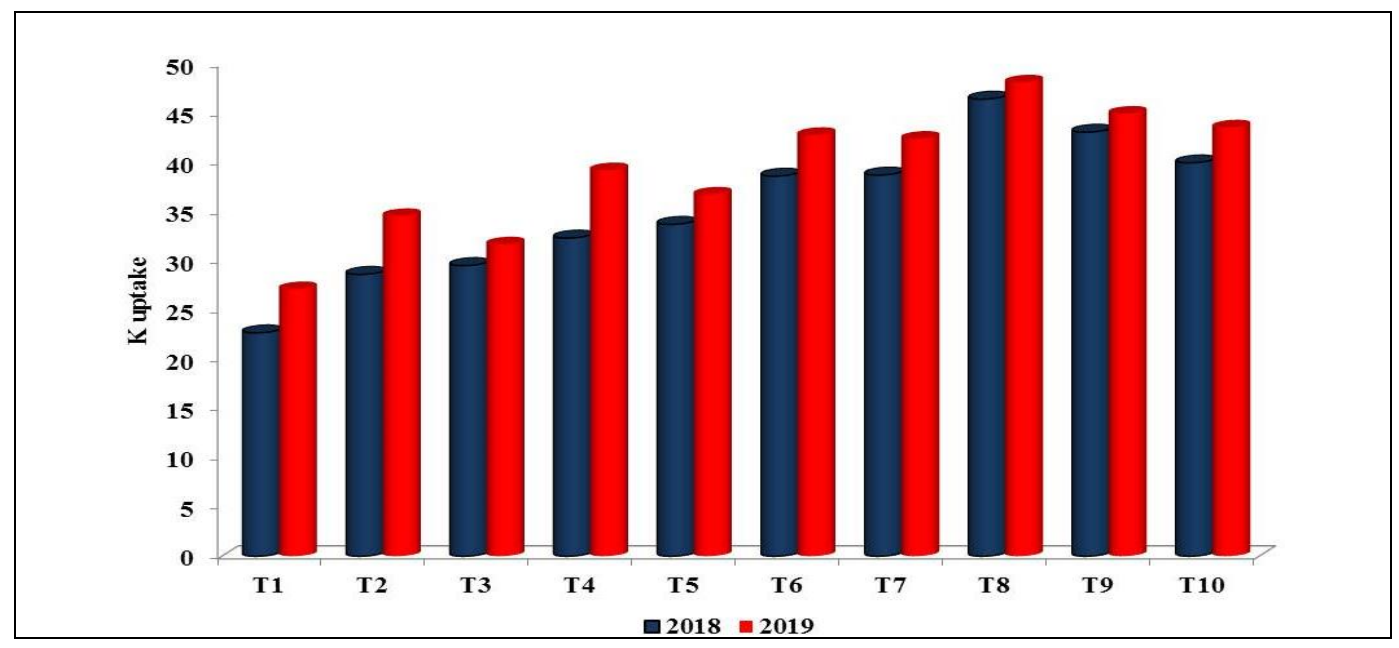

Fig 2: Potassium uptake $\left(\mathrm{kg} \mathrm{ha}^{-1}\right)$ as affected by different treatments in 2018 and 2019 seasons.

Where is:

T1: Control

T2: 50\%SA+1 NPK FA

T3: $50 \% \mathrm{SA}+1 \mathrm{~N} \mathrm{FA}$

T4: 50\%SA+2 NPK FA

T5: 50\%SA+2 N FA
T6: 75\%SA+1 NPK FA

T7: 75\%SA+1 N FA

T8: 75\%SA+2 NPK FA

T9: 75\%SA+2 N FA

T10: $100 \%$ SA 
The increase in NPK uptake with foliar application of NPK at different growth stages could be attributed also to reduce losses of nutrients and enhance fertilizer use efficiency. A similar trend was found by Jagathjothi et al., (2012) and Hashem (2019).

Figures 3 and 4 illustrate the total revenue and benefits/costs of different treatments. It was observed that the maximum variable and total costs were recorded when $100 \%$ of nitrogen recommended dose were applied. Application of (123.75 kg N ha-1 combined with NPK foliar application or $\mathrm{N}$ two times) recorded the highest values of gross return and net return as well as benefit cost ratio.

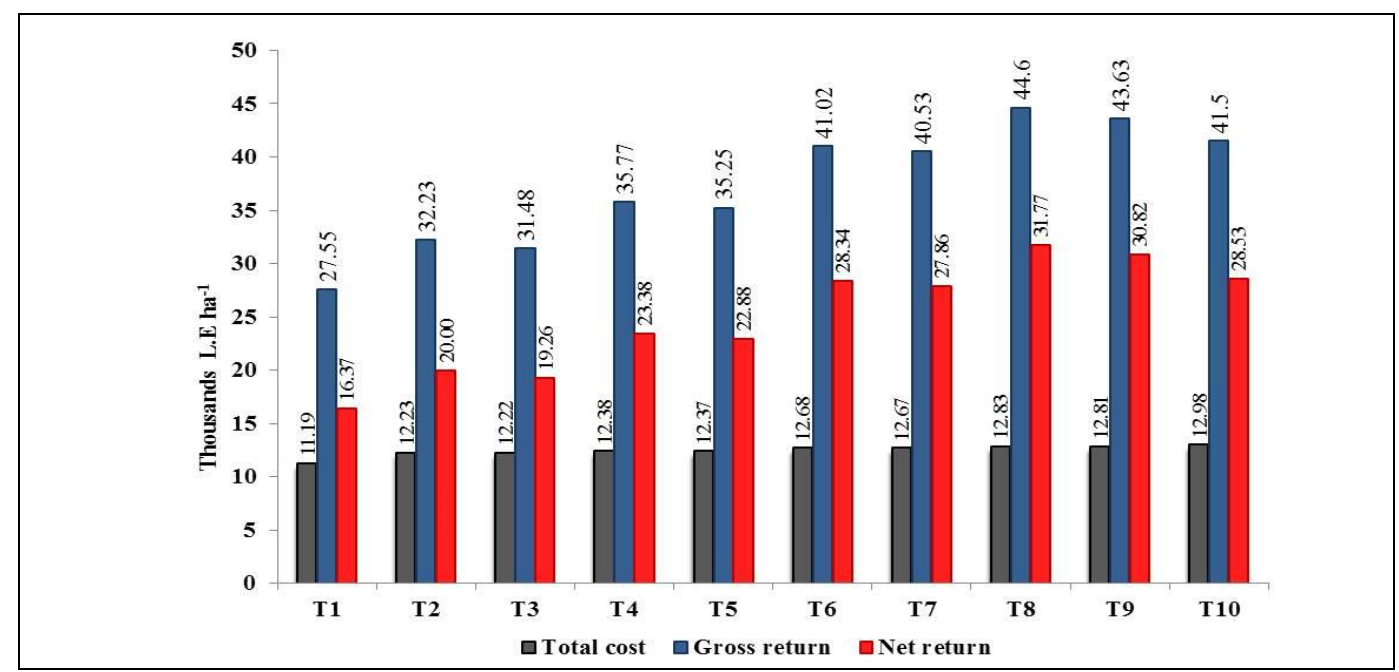

Fig 3: Total cost, gross returns and net return (L.E. ha-1) as overall mean values through the two growing seasons.

Where is:

T1: Control

T2: $50 \% \mathrm{SA}+1 \mathrm{NPK} F A$

T3: $50 \% \mathrm{SA}+1 \mathrm{~N}$ FA

T4: 50\%SA+2 NPK FA

T5: 50\%SA+2 N FA
T6: 75\%SA+1 NPK FA
T7: 75\%SA+1 N FA
T8: $75 \% \mathrm{SA}+2 \mathrm{NPK} F A$
T9: 75\%SA+2 N FA
T10: $100 \%$ SA

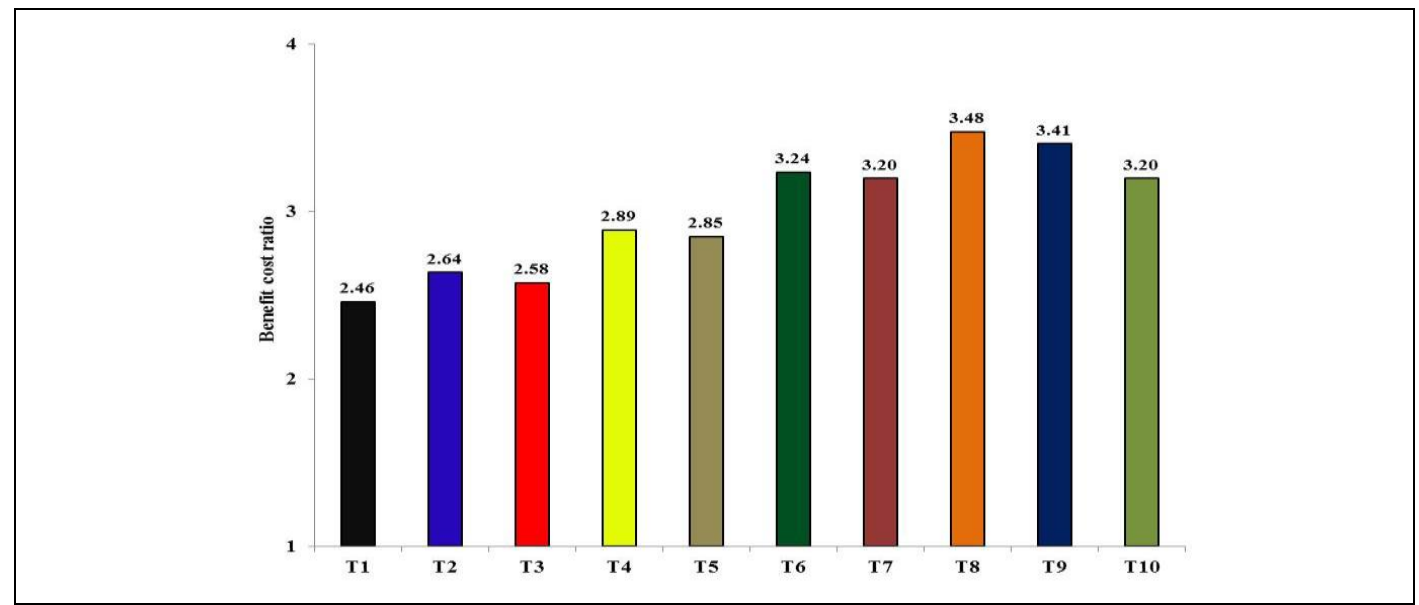

Fig 4: Benefit: cost ratio of straw and grain yield (t. ha $\left.{ }^{-1}\right)$ as influenced by different treatments overall means value through the two growing seasons.
Where is:
T1: Control
T2: 50\%SA+1 NPK FA
T3: $50 \% \mathrm{SA}+1 \mathrm{~N}$ FA
T4: 50\%SA+2 NPK FA
T5: $50 \% \mathrm{SA}+2 \mathrm{~N}$ FA

T6: $75 \% \mathrm{SA}+1$ NPK FA

T7: 75\%SA+1 N FA

T8: $75 \% \mathrm{SA}+2$ NPK FA

T9: $75 \%$ SA+2 N FA

T10: $100 \%$ SA 
Meanwhile, there were insignificant differences in gross return, net return and benefit cost ratio among application of recommended dose and Application of (123.75 kg N ha ${ }^{-1}$ combined with NPK foliar application or $2 \% \mathrm{~N}$ one application). Hashem (2019) reportet that, gross return and net returns were highest when rice plant treated by two thirds of NPK (urea, super phosphate, potassium sulphate) as basal dose + foliar spray of NPK (28:28:28) $2.5 \mathrm{~kg}$ ha $^{-1}$ compared to recoomended dose of NPK and control.

\section{CONCLUSION}

Foliar application of NPK or N may cause a significant increase in rice productivity as well as increase the benefit cost ration. Rice grain yield was significantly increased by application of either the recommended $\mathrm{N}$ rate alone $\left(165 \mathrm{~kg} \mathrm{~N} \mathrm{ha}^{-1}\right)$ or the nitrogen rates of $\left(123.75 \mathrm{~kg} \mathrm{~N}^{-1}\right.$ and $82.5 \mathrm{~kg} \mathrm{~N}$ ha $^{-1}$ with NPK and N foliar spray of once and twice) compared with the control treatment. Application of (123.75 $\mathrm{kg} \mathrm{N} \mathrm{ha}^{-1}$ combined with foliar application of NPK or N two times) recorded the highest values of gross return and net return as well as benefit cost ratio.

\section{REFERENCES}

Alam, S., A. Moslehuddin, M. Islam, and A. Kamal (2010). Soil and foliar application of nitrogen for Boro rice (BRRIdhan 29), Journal of the Bangladesh Agricultural University, 8(2), 199202.

Das, C. K., H. Jangir, J. Kumar, S. Verma, S. S. Mahapatra, D. Philip, G. Srivastava, and M. Das (2018). Nano-pyrite seed dressing: a sustainable design for NPK equivalent rice production, Nanotechnology for Environmental Engineering, 3(1), 1-14.

Duncan, O. D., and B. Duncan (1955). A methodological analysis of segregation indexes, American sociological review, 20(2), 210-217.

Gomez, K., A. Gomez (1984). Statistical procedures of agricultural research. - John Wiley and Sons. Inc., New York, U.S.A.

Hashem, I. (2019). Studies on the effect of foliar fertilizer application in combination with conventional fertilizers on rice production, Journal of Plant Production, 10(6), 447-452.

Hervé, D. S., M. G. Annih, M. D. Kenyi, and S. Christopher (2017). Effect of different doses of NPK fertilizer on the growth and yield of rice in Ndop, North West of Cameroon, African Journal of Agricultural Research, 12(15), 12441252.
Jackson, M. L. (1967). Soil chemical analysis prentice hall of Indica, New Delhi. Jat. (pp.144197).

Jagathjothi, N., P. Muthukrishnan, and M. M. Amanullah (2012). Influence of foliar nutrition on growth and yield of transplanted rice, Madras Agricultural Journal, 99(4/6), 275-278.

Kundu, C., and R. Sarkar (2009). Effect of foliar application of potassium nitrate and calcium nitrate on performance of rainfed lowland rice (Oryza sativa), Indian Journal of Agronomy, 54(4), 428-432.

Manik, I. H., M. A. Abedin, M. R. Rahman, T. Chakrobarty, S. B. Jaman, M. Al Noor, and R. Sultana (2016). Reducing urea demand for rice crop through foliar application of urea in boro season, Research in Agriculture Livestock and Fisheries, 3(1), 79-85.

Metwally, T., A. Mohamed, S. Sorour, and G. Elsayed (2020). Stimulating compounds affect the grain quality characteristics and the nutritional value of rice (Oryza sativa), Applied Ecology and Environmental Research, 18(5), 6829-6840.

Mohan, A., A. Tiwari, M. Kumar, D. Pandey, A. Singh, and B. Singh (2017). Effect of foliar spray of various nutrients on performance of rainfed rice (Oryza sativa L.), J. of pharmacognosy and phytochem, 6(5), 22522256.

Okasha, A. M., M. Abbelhameed, and O. M. Elshayb (2019). Improving rice grain quality and yield of giza 179 rice cultivar using some chemical foliar spray at late growth stages under salt stress, Journal of Plant Production, 10(9), 769-775.

Pan, S., F. Rasul, W. Li, H. Tian, Z. Mo, M. Duan, and X. Tang (2013). Roles of plant growth regulators on yield, grain qualities and antioxidant enzyme activities in super hybrid rice (Oryza sativa L.), Rice, 6(1), 1-10.

Peterburgski, A. (1968). Hand book of agronomic chemistry. Kolos Puplishing House, Moscow, Russian, (pp. 29-86).

Program, C. E., Maize, I., and Center, W. I. (1988). From agronomic data to farmer recommendations: an economics training manual," CIMMYT".

Rani, B. S., T. G. Krishna, and P. Munirathnam (2014). Studies on the effect of foliar fertilization in combination with conventional fertilizers on yield, economics and nutrient uptake of rice (Oryza sativa L.) under KC Canal Ayacut area of Andhra Pradesh, India, Agricultural Science Digest, 34(1),15-20. 
Shrestha, J., K. K. Shah, and K. P. Timsina (2020). Effects of different fertilizers on growth and productivity of rice (Oryza sativa L.): A review, International Journal of Global Science Research, 7(1), 1291-1301.
Wu, L., S. Yuan, L. Huang, F. Sun, G. Zhu, G. Li, S. Fahad, S. Peng, and F. Wang (2016). Physiological mechanisms underlying the highgrain yield and high-nitrogen use efficiency of elite rice varieties under a low rate of nitrogen application in China, Frontiers in plant science, $7,1024$.

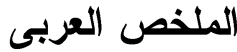

\section{تأثير الرش الورقي بالسماد المركب النيتروجين والفسفور والبوتاسيوم علي انتاجية وجودة

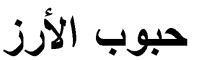

\author{
عبدالفتاح صبحي غريب \\ مركز البحوث و التدريب في الارز - معهد بحوث المحاصيل الحقلية- مركز البحوث الزر اعية- كفر الثيخ- مصر
}

أجريت تجربتان حقليتان بالمزرعة البحثية لمركز البحوث الزراعية- محطة البحوث الزراعية بسخا -

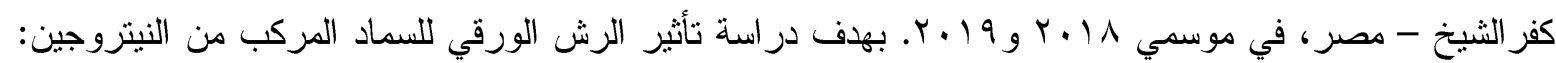

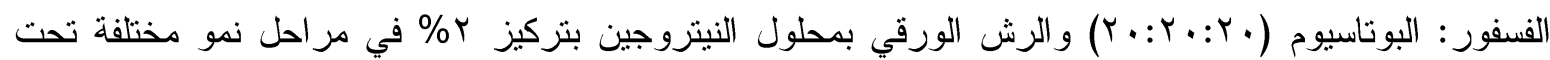

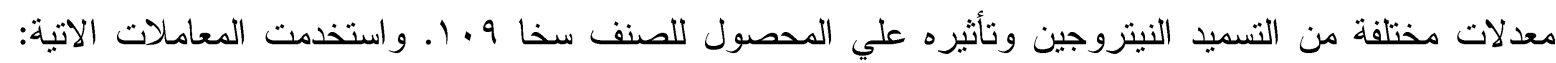
معاملة المقارنة بدون اضافة نيتزوجين (رش بالماء)- الكمية الموصي بها من التسميد النيتروجين (10 (10 وحدة

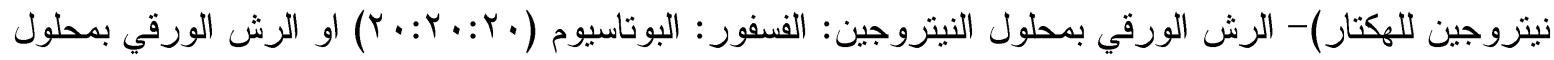

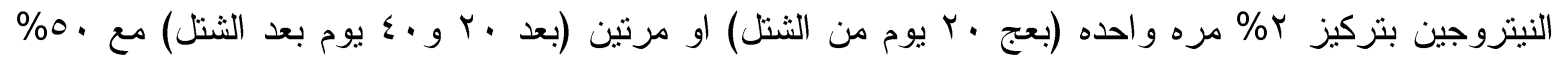

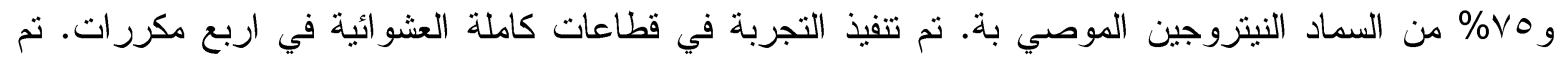
قياس الصفات التالية محتوي الكلورفيل (SPAD value)، ارتفاع النبات (سم)، عدد السنابل في الجورة، طول السنبلة

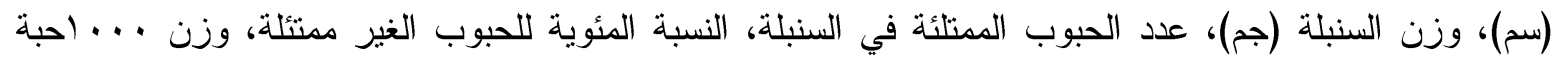
(جم)، محصول الحبوب (طن للهكتار)، محصول القش (طن للهكتار)، صفات الجودة، معدل امتصاص الحبوب لكلا من النيتروجين و البوتاسيوم بالاضافة الي التقيم الاقتصادي. اظهرت النتائج ان كل الصفات المدروسة تأثرت معنويا

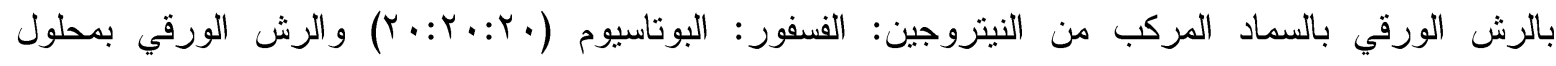
النيتروجين بتركيز r\% في مراحل النمو المختلفة. اظهرت النتائج ان الرش الورقي للسماد الورقي المركب من وبرد

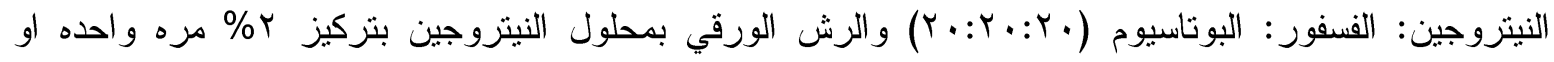

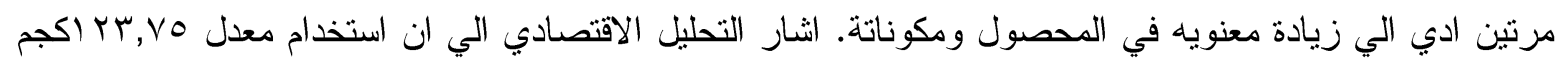

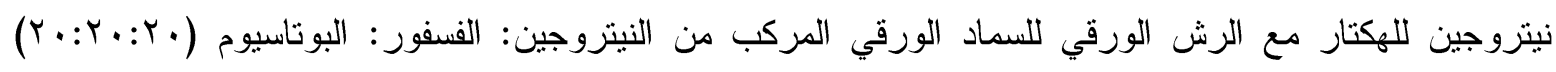

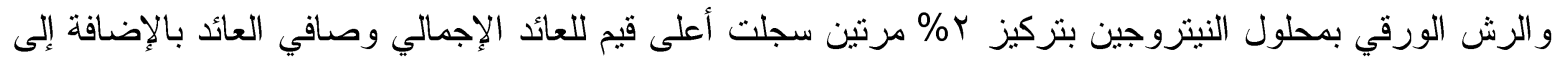

